\title{
Diet of fish populations in posidonia oceanica meadows off the Island of Ischia (Gulf of Naples, Italy): assessment of spatial and seasonal variability
}

\author{
Valerio Zupo $^{1^{*}}$, Dorothea Stübing ${ }^{2}$ \\ ${ }^{1}$ Functional and Evolutionary Ecology Lab. Stazione Zoologica Anton Dohrn. Punta San Pietro, Ischia. Italy; *Corresponding author: \\ vzupo@szn.it \\ ${ }^{2}$ Marine Zoology, University of Bremen, Bremen, Germany
}

Received 25 June 2010; revised 28 July 2010; accepted 5 August 2010.

\section{ABSTRACT}

The gut contents of fish in three Posidonia oceanica meadows off the island of Ischia (Bay of Naples, Italy) were investigated. A total of 926 individual fish belonging to 28 species was sampled by bottom trawl in the leaf canopy. Labridae, Pomacentridae, Scorpaenidae, and Serranidae were the best represented families $(41 \%, 38 \%, 8 \%$ and $6 \%$ of the total number of individuals, respectively). Of the 94 taxa detected in the gut contents, 42 were identified to the species level. The most common food items were decapod crustaceans $(15 \%$ of the gut contents, on average), copepods (13\%), amphipods $(14 \%)$, brown fragments of $P$. oceanica $(6 \%)$, and ostracods (6\%). The most abundant species of labridae, Symphodus ocellatus and $S$. rostratus, showed a broad spectrum of prey. This generalist feeding may positively influence their numerical abundance. Seasonal variations in the diets of fish, also at prey-species level, were demonstrated. The fish taxon plays essentially a macro-carnivore trophic role. In the investigated seagrass meadows the main trophic fluxes start from plant detritus, macrophyta, and microphyta (as primary producers) towards crustacean decapods, copepods, ostracods, and gammarid amphipods (as secondary producers) to fish. A low recycling rate (4\%) within the fish community was observed. Larger fish predators (e.g., Sparidae), swimming over the leaf canopy, are the main exporters to adjacent coastal systems.

Keywords: Fish; Food Webs; Spatial Variability; Posidonia Oceanica; Seagrass; Seasonality

\section{INTRODUCTION}

The presence of seagrasses provides effective protection against predation [1-3]; therefore it is accompanied by a great abundance of small invertebrates [4-6]. In fact, the 3-dimensional complex structure provided by seagrasses represents a clear advantage for several invertebrates, as well as for young fish, that find refuge from predation [7]. It has been demonstrated that the capture success of predators is generally higher over bare substrates than in seagrass meadows and this leads settling larvae, juveniles and adults towards coastal meadows [8]. A rich fish population inhabits the seagrass meadows, because it is attracted to the abundant food (i.e., small invertebrates; [9]) and to the shelter from predators typically provided by these structured habitats. In fact, seagrass meadows play the role of nurseries for important fish species $[10,11]$ that, along with decapod crustaceans $[12,13]$, are important consumers of secondary production in these systems [14-16]. According to [7], the relative value of seagrasses as predation defense is correlated to the relative abundance of ambush-, stalkand chase-attack predators inhabiting seagrass and neighboring substrata.

Several authors have investigated the structure of the food webs in Posidonia oceanica meadows (e.g., [5,17-19]). However, there is still a remarkable lack of information on the main pathways of transfer from the plant level to the highest trophic levels $[20,21]$. In particular, the fate of secondary production in the food webs of $P$. oceanica meadows is partially unknown. Although fish are hypothesized to be the highest level consumers of secondary production in seagrass meadows [22,23] and in other environments [24], the rate and the pathways of transfer are still uncertain.

Another important feature of Mediterranean sea- 
grass meadows is their seasonality. Such seagrasses as $P$. oceanica are stable and time-persistent, but their canopy exhibits important seasonal variations due to the characteristic rhythm of growth [17]. These variations are also in accordance with dramatic shifts in the amount of detritus and epiphytes available [25,26]. In addition, seasonal differences in abundance and composition of associated invertebrate populations were observed in the leaf stratum [27]. Similar variations may be observed among differently exposed meadows. In fact, $P$. oceanica beds located in areas influenced by high hydrodynamic pressure exhibit lower abundance of detritus and different epiphyte associations, as compared to meadows exposed to low hydrodynamic forces $[2,5]$. Due to these spatial and temporal differences in the abundance of potential prey, the general assumption that fish represent important predators for selected invertebrates living in the leaf stratum of seagrasses $[1,14,16]$ should be confirmed by direct data.

The feeding behaviour of fish living within the leaf canopy of three $P$. oceanica meadows has been investigated in the present paper, through the analysis of their gut contents, to assess their role in the consumption of secondary production in two seasons and, therefore, the impact of fish predation [28] on invertebrate populations. Our major questions were: 1) Which is the trophic role played by fish in a range of $P$. oceanica meadows? 2) Are the trophic guilds exhibited by selected species of fish stable in space and time, or are they adapted to spatial and seasonal variations in the structure of the associated algal and animal communities? 3) May fish be considered the highest-level consumers of secondary production in seagrass meadows?

\section{MATERIAL AND METHODS}

This investigation was carried out on Posidonia oceanica meadows off the island of Ischia (Gulf of Naples, Italy; Figure 1), extending from 1 to about $30 \mathrm{~m}$ depth. Samples were collected at three meadows differently exposed: 1) Lacco Ameno Bay, on the northern sector

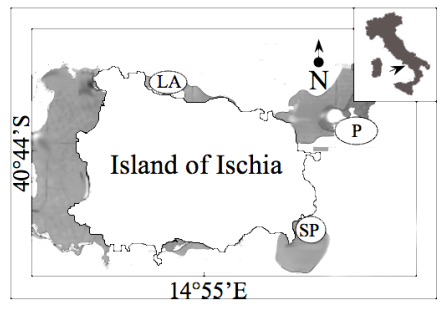

Figure 1. Map of the sampling area and location of the three sampling sites. LA: Lacco Ameno; P: Channel between Ischia and Procida; SP: Cape S. Pancrazio. of the island; 2) the channel between Ischia and the island of Procida, on the eastern side of the island of Is-chia, and 3) off Cape San Pancrazio, on the south-east side. Samples were collected in winter (March) and summer (July) on P. oceanica meadows, at depths between 17 and $20 \mathrm{~m}$. This depth was selected as it corresponds to the "intermediate" meadow (as described by [5]), whose animal populations can be regarded as representative of the whole system. It is more stable than the shallow meadow, less exposed to environmental disturbances, and exhibits a higher structural complexity than the deep meadow $[5,17]$. The two sampling seasons chosen correspond, respectively, to the periods before and after the reproduction of several species of benthic invertebrates. We selected these periods also to point out any difference in the diet of fish due to variations in the availability of their prey.

Previous authors [29] investigated the methodological bias of sampling instruments applied to the same ecosystem studied in the present paper and they determined that skid trawls can efficiently sample the fish assemblage living close to the canopy. Therefore, a skid trawl with a frame of $1.5 \times 0.5 \mathrm{~m}$ and a mesh of $8 \mathrm{~mm}$ was used, according to the technique described by [30]. Four replicates were collected in each site around noon, both in summer and in winter. Each replicate was obtained by towing the skid for 5 minutes at a constant speed of 1 knot, to cover an area of about $250 \mathrm{~m}$. All fish collected were preserved in $10 \%$ buffered formalin.

Individual fish were identified to the species level, measured (total length), weighed (fresh weight), and dissected for the analysis of gut contents. Gut contents were examined under a dissecting microscope and, when necessary, permanent slides were prepared and analysed under a compound microscope. Each prey was identified to the lowest possible taxonomic level and its abundance was evaluated assigning a score from 0 to 4 (i.e., $0 \%$, $25 \%, 50 \%, 75 \%$, and $100 \%$ of the total gut volume, respectively). Least abundant food items were pooled into larger taxa, to obtain a matrix "species vs. food items" for statistical analyses. The ratio between total gut content of each individual and the gut volume was indicated by a score (from 0 to 4 , as above mentioned), to quantify gut "fullness". This technique was used to obtain a quantitative estimation of the whole gut content, avoiding the experimental error due to the immersion in formalin and to the high fragmentation of some materials [31,32].

Fish populations were statistically analysed to detect variations in their composition, among replicates, sites and seasons. Differences among individual samples were tested by one-way analysis of variance (ANOVA). The significance of differences among individual diets was evaluated by $t$-test. The diets of the most abundant fish 
species were analysed for variation in their food sources as a function of the sampling site and season. Gut content data were analysed by the technique described by [18], to classify species in homogeneous trophic groups and obtain an ordination of fish trophic groups according to the site and the season of sampling [27]. The technique involves the calculation, for each species in each sample, of two indices defining a trophic category, based on average prey "type" (plant or animal) and "size" (taking into account the average size in millimetres of each prey item). In particular, the two indices were obtained by the following formulae:

a) Prey type index:

$$
\text { Type }_{i}=\left(\sum V_{i}-\sum C_{i}\right) / \sum M_{i j}
$$

b) Prey size index:

$$
\text { Size }_{i}=\operatorname{In}\left(\sum\left(P S_{j} \times M_{i j}\right) / \sum M_{i j}\right)
$$

with:

$=$ abundance of plant items;

$=$ abundance of animal items;

= abundance of each considered item;

$=$ mean prey size (measured in $\mathrm{mm}$ ).

This technique allows for an ordination of species in Cartesian plots showing feeding preferences, to compare the results obtained at different sites or during different seasons, and to simplify the understanding of complex ecosystem food webs. In fact, the positions of species in the 4 quarters of the plot indicate their feeding habits: macro-herbivores are ordered in the $1^{\text {st }}$ sector (upper right), micro-herbivores in the $2^{\text {nd }}$ sector (lower right), micro-carnivores in the $3^{\text {rd }}$ sector (lower left), macro-carnivores in the $4^{\text {th }}$ sector (upper left), omnivores are close to the centre of axes. The information collected was used to draw the main trophic relationships in the considered system.

\section{RESULTS}

\subsection{Fish Populations}

No significant differences between the four replicates of each sample were found (ANOVA; $\mathrm{p}<0.01$ ). Therefore, the specimens collected in each set of four parallel replicates were pooled, prior to be subjected to trophic analyses. A total of 926 individual fish, belonging to 28 species (Table 1), was sampled, identified, and analysed. The most abundant families were Labridae $(41 \%$ of all individuals), Pomacentridae (39\%), Scorpaenidae $(8 \%)$ and Serranidae (6\%). The most abundant species (Figure 2) were Chromis chromis (356 ind.; 38\%); Symphodus ocellatus (187 ind.; 20\%) and S. rostratus (134 ind.; $14 \%$ ). The total number of species and individuals in each sample varied according to the site and the season

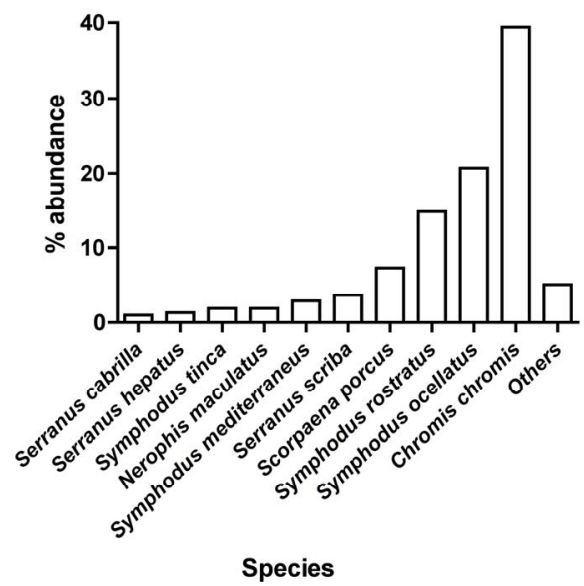

Figure 2. Percent abundance of the most abundant fish species in all samples (pooled).

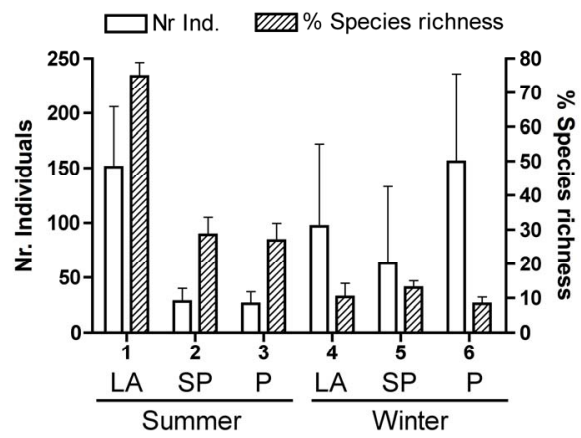

Figure 3. Mean number of individuals collected (left axis) and species richness (right axis) for each sample. LA, Lacco Ameno; SP, S. Pancrazio; $\mathrm{P}$, Channel of Procida. The first three collections were performed in summer, the other three in winter. Standard deviations among the four replicates are indicated by error bars.

and it was highest in Lacco Ameno in summer (Figure 3).

The total number of species per sample varied between 7 (at the Procida channel, summer) and 16 (at Lacco Ameno, summer). The biomass of species sampled in winter was constantly higher than in summer, with the exception of the families Pomacentridae and Congeridae. Labridae reached a winter biomass of about $2 \mathrm{~g} \mathrm{~m}^{-2}$ (fresh weight) in the sampled meadows. The families Labridae, Pomacentridae and Serranidae accounted for $98 \%$ of the total fish biomass. Most individuals were small in comparison to the maximum size reached by the species (Table 1). Large intra-specific size variations were observed mainly in the samples collected at Lacco Ameno.

\subsection{Analysis of Gut Contents}

Ninety-four food items were identified in the guts. 
Table 1. Fish species collected, total number of individuals collected in all the samples (pooled), mean length (cm total length) and mean weight ( $\mathrm{g}$ wet weight) of each species.

\begin{tabular}{|c|c|c|c|c|c|}
\hline Nr. & Species & & Total & Mean & Mean \\
\hline & & & nr. ind. & length $(\mathrm{cm})$ & weight (g) \\
\hline 1 & Chromis chromis & (Linnaeus, 1758) & 356 & 5.43 & 7.37 \\
\hline 2 & Symphodus ocellatus & Forsskal, 1775 & 187 & 6.04 & 1.07 \\
\hline 3 & Symphodus rostratus & (Block, 1797) & 134 & 8.41 & 13.52 \\
\hline 4 & Scorpaena porcus & Linnaeus, 1758 & 69 & 8.48 & 4.82 \\
\hline 5 & Serranus scriba & (Linnaeus, 1758) & 42 & 11.01 & 3.75 \\
\hline 6 & Symphodus mediterraneus & (Linnaeus, 1758) & 26 & 5.57 & 4.65 \\
\hline 7 & Nerophis maculatus & Rafinesque, 1810 & 17 & 20.61 & 14.75 \\
\hline 8 & Symphodus tinca & (Linnaeus, 1758) & 17 & 12.48 & 1.03 \\
\hline 9 & Gobius cruentatus & Gmelin, 1789 & 15 & 4.60 & 0.93 \\
\hline 10 & Serranus hepatus & (Linnaeus, 1758) & 12 & 6.22 & 10.16 \\
\hline 11 & Syngnathus acus & Linnaeus, 1758 & 8 & 20.76 & 0.76 \\
\hline 12 & Arnoglossus kessleri & Schmidt, 1915 & 6 & 5.00 & 2.78 \\
\hline 13 & Symphodus cinereus & (Bonnaterre, 1788) & 6 & 7.73 & 67.20 \\
\hline 14 & Scorpaena notata & Rafinesque, 1810 & 5 & 8.43 & 0.99 \\
\hline 15 & Apogon imberbis & (Linnaeus, 1758) & 4 & 8.08 & 3.52 \\
\hline 16 & Gobius geniporus & Valenciennes, 1837 & 3 & 4.75 & 0.96 \\
\hline 17 & Labrus viridis & Linnaeus, 1758 & 3 & 13.65 & 35.31 \\
\hline 18 & Mullus surmuletus & Linnaeus, 1758 & 3 & 7.40 & 4.04 \\
\hline 19 & Conger conger & (Linnaeus, 1758) & 2 & 24.05 & 12.41 \\
\hline 20 & Diplodus annularis & (Linnaeus, 1758) & 2 & 12.60 & 3.59 \\
\hline 21 & Serranus cabrilla & (Linnaeus, 1758) & 2 & 10.01 & 18.83 \\
\hline 22 & Bothus podas & (Delaroche, 1809) & 1 & 4.80 & 1.27 \\
\hline 23 & Coris julis & (Linnaeus, 1758) & 1 & 8.80 & 20.87 \\
\hline 24 & Deltentosteus quadrimaculatus & (Valenciennes, 1837) & 1 & 6.26 & 4.87 \\
\hline 25 & Gobius vittatus & Vinciguerra, 1883 & 1 & 5.25 & 1.12 \\
\hline 26 & Spicara maena & (Linnaeus, 1758) & 1 & 10.80 & 14.51 \\
\hline 27 & Symphodus doderleni & Jordan, 1891 & 1 & 3.90 & 31.37 \\
\hline 28 & Symphodus melanocercus & (Risso, 1810) & 1 & 4.80 & 0.49 \\
\hline
\end{tabular}

Scarcely abundant food items were pooled into larger taxa and a matrix containing 28 species of fish (Table 1) and 30 food items (Table 2) was obtained. The most abundant species, Chromis chromis, fed mainly on plankton items, besides molluscs and decapods. In contrast, the two most abundant species of Labridae, Symphodus ocellatus and S. rostratus, fed on a wide spectrum of food items shared with the whole fish population. Their diet profiles, however, were different, since $S$. ocellatus fed mainly on copepods and other crustaceans, while S. rostratus exhibited a wider spectrum of preferences, including plathelminthes, small crustaceans, natantia decapods, and Posidonia tissues. Another important species of Labridae, Symphodus mediterraneus, showed a narrower dietary spectrum (21 items) and fed preferentially on brown Posidonia tissues, copepods, reptantia decapods, and other animal items. Serranus scriba, S. cabrilla and Scorpaena porcus, among the other abundant species, fed preferentially on natantia and reptantia decapods, but they exhibited a wide dietary spectrum, including Posidonia tissues, amphipods, and other animal items.

The ordination of species according to the "Type" and "Size" indices [18] indicated that the fish community plays essentially a macro-carnivore trophic role (Figure 4): species were all ordered in the 4th sector, in a compact cluster. An exception was represented by Coris julis and Spicara maena, exhibiting a "microphagous" feeding pattern, and Scorpaena notata and Symphodus cinereus, clustered towards a position indicating herbivorous 
Table 2. Food items taken into account in the present investigation and their average abundance ( $\%$ of gut contents) in all samples.

\begin{tabular}{lc}
\hline \multicolumn{1}{c}{ Prey item } & \% abundance \\
\hline 1) Copepods & 12.93 \\
2) Gammarid amphipods & 10.06 \\
3) Natantia decapods & 9.26 \\
4) Unidentified animal tissues & 8.57 \\
5) Reptantia decapods & 6.45 \\
6) Brown tissues of Posidonia & 6.37 \\
7) Ostracods & 6.23 \\
8) Unidentified crustaceans & 6.01 \\
9) Isopods & 4.29 \\
10) Caprellid amphipods & 3.93 \\
11) Fish & 3.81 \\
12) Macroalgae & 3.19 \\
13) Unidentified decapods & 2.5 \\
14) Plathelminthes & 2.37 \\
15) Mysidaceans & 2.32 \\
16) Nematodes & 2.22 \\
17) Tanaidacea & 1.87 \\
18) Polychaetes & 1.54 \\
19) Gastropod molluscs & 1.12 \\
20) Unidentified vegetal tissues & 0.79 \\
21) Eggs & 0.78 \\
22) Acarids & 0.66 \\
23) Foraminiferans & 0.64 \\
24) Microalgae & 0.59 \\
25) Sipunculids & 0.4 \\
26) Pantopods & 0.4 \\
27) Cumaceans & 0.29 \\
28) Unidentified molluscs & 0.17 \\
29) Bivalve molluscs & 0.16 \\
30) Echinoderms & 0.06 \\
\hline
\end{tabular}

feeding habit. Chromis chromis occupied a polar position, also indicating a microcarnivorous diet. The most abundant labridae, S. ocellatus and S. rostratus, were in a central position in the cluster. Besides the above exceptions, all the Scorpaenidae and Serranidae were grouped in a central compact sub-cluster.

Seasonal variations in the feeding habits of some species were observed (Figure 5). In summer Labrus viridis and $S$. cinereus exhibited a more "herbivorous" habit than in winter. In winter $S$. ocellatus preyed almost entirely on animals, while in summer it fed mainly on plant matter. S. rostratus did not change its feeding preferences (plant or animal) between the two seasons. No variations in the "Size" index were observed between the two seasons for any species, but the dietary composition changed. The total number of prey items of $S$. ocellatus

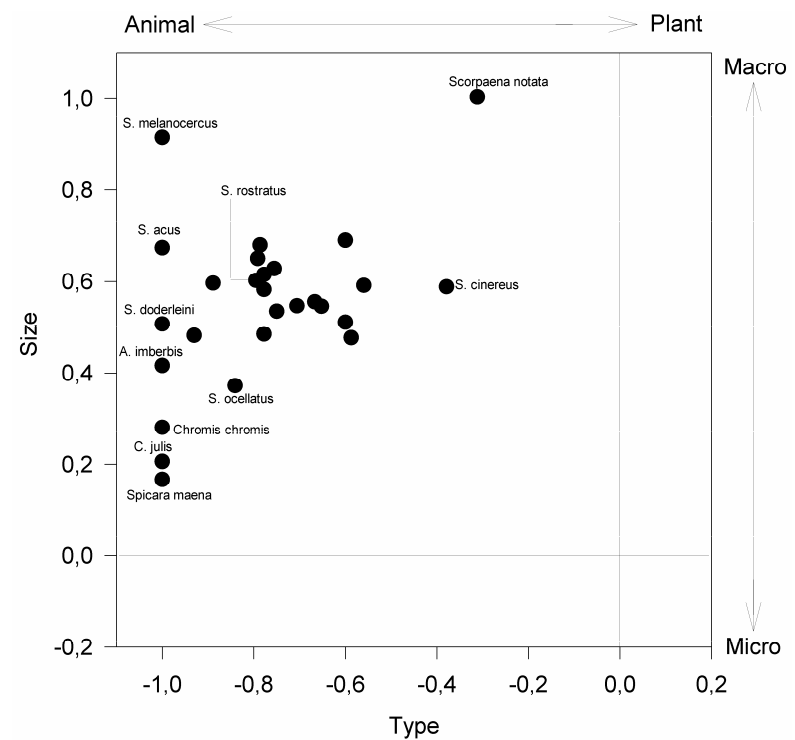

Figure 4. Ordination in the "Type-Size" space of the species collected in all the samples. The horizontal axis discriminates the "type" of diet (based on the abundance of plant or animal prey items); the vertical axis discriminates the "size" of diet (based on small or large prey items). Circles indicate the position of each species of fish (the most abundant are specified).

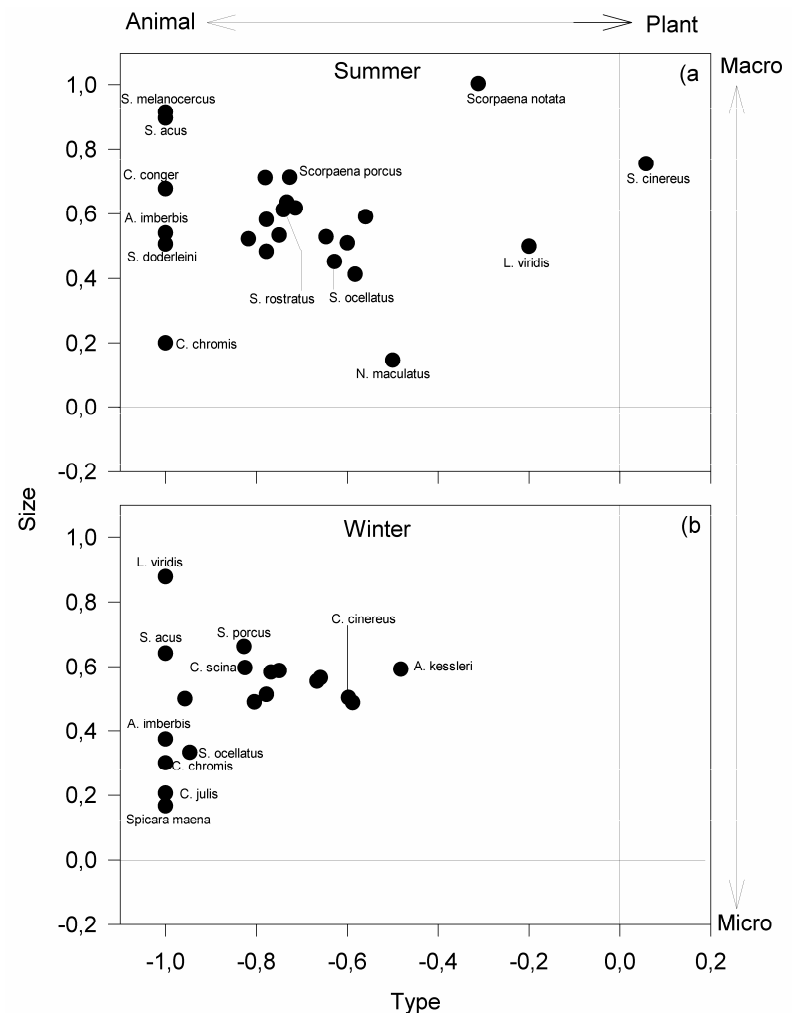

Figure 5. Ordination in the "Type-Size" space of the species according to the season of sampling (a, summer; $b$, winter). The horizontal axis discriminates the "type" of diet (based on the abundance of plant or animal prey items); the vertical axis discriminates the "size" of diet (based on small or large prey items). Circles indicate the position of each species of fish (the most abundant are specified). 
significantly changed according to the season. In fact $S$. ocellatus fed on 24 prey items in summer, and 20 in winter, when its diet was mainly based on copepods (32\% of gut contents).

In contrast, the total number of prey items of $S$. rostratus was constant (24) in the two seasons and no significant differences were observed in the food composition.

Other species, such as Serranus scriba and Scorpaena porcus, exhibited a comparable reduction of plant items in winter, and different feeding preferences in the two seasons, as revealed by the "Type-Size" ordinations.

The samples obtained at Lacco Ameno (Figure 6(a)) and San Pancrazio (Figure 6(c)) clustered according to prey size, more tightly in respect to the Channel of Procida (Figure 6(b)). In particular, such species as Mullus sur

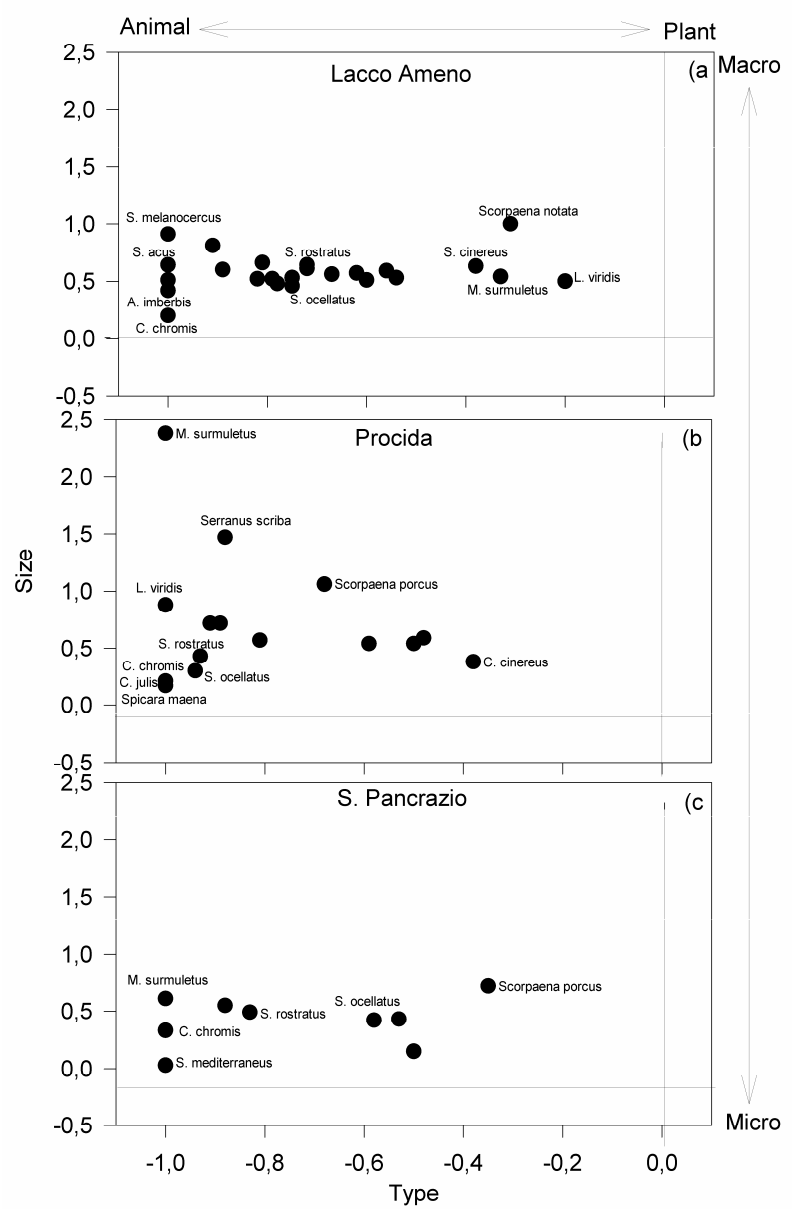

Figure 6. Ordination in the "Type-Size" space of the species according to the site of sampling ( $a$, Lacco Ameno; b, Procida; c, S. Pancrazio). The horizontal axis discriminates the "type" of diet (based on the abundance of plant or animal prey items); the vertical axis discriminates the "size" of diet (based on small or large prey items). Circles indicate the position of each species of fish (the most abundant are specified). muletus, Serranus scriba, and Scorpaena porcus, occupied a higher position along the "Size" axis in the samples of the Channel of Procida, indicating a feeding habit with a stronger "macrophagous" character. No significant variations in the diet were detected by ANOVA between Lacco Ameno and the other two sites.

The analysis of diets indicated that the main prey items of fish (Table 2), were copepods (12,93\% of their gut contents, on average), gammarid amphipods (10,06\%), Natantia decapods (about 9\%) and, besides unidentified animal tissues (8,57\%), Posidonia tissues $(6,37 \%)$ and ostracods $(6,23 \%)$. Seasonal variations of the diet were observed (Table 3) at lower taxonomic levels. The basic structure of the fish food webs was traced based on previous data (Figure 7) and the abundances (volumes occupied in the gut contents of fish) of each item in the food webs were organised to permit a comparison of their relative importance. The most abundant items (in terms of volume occupied in the guts) were copepods, amphipods, decapods and other crustaceans.

\section{DISCUSSION}

The skid trawl, as demonstrated by [29], is a suitable sampling tool to obtain a representative picture of the fish fauna living within the Posidonia oceanica meadows, allowing for the study of the upper levels of local food webs [30,31]. Other sampling methods, however, may complete the information on the fish assemblage of meadows, in particular on upper water dwellers, feeding mainly on planktonic micro-crustaceans or other fish $[21,29]$. The efficiency of the trawl was higher in winter, when the canopy was lower. The investigated meadows were characterised by benthic families of fish (Labridae, Pomacentridae, Scorpaenidae, Sygnathidae, Serranidae) although a few individuals were found that belonged to families with good swimming capabilities (e.g., Sparidae). The number of species collected during this investigation was lower than the number of species found in French meadows of $P$. oceanica meadows using an identical sampling technique (28 as compared to 49 species; [33]). The difference may be due to a higher fishing pressure characterising the meadows investigated in the present paper, in accordance with the results of previous studies [29].

Fresh weight estimates showed the importance of the main three families, i.e., Labridae, Pomacentridae and Scorpaenidae. In fact, they accounted for $99.4 \%$ of the total fish biomass sampled in summer and for $93.7 \%$ of the total fish biomass sampled in winter $(98 \%$ of the total fish biomass throughout the year).

The high fish biomass collected in winter was not correlated with individual fish weight. It was due to a 
Table 3. Prey found in the gut contents of the most abundant species of fish collected. A grey square indicates the presence of each prey in summer (S) and/or winter (W) samples.

\begin{tabular}{|c|c|c|}
\hline Fish & $\mathbf{S} \mathbf{W}$ & Prey \\
\hline \multirow[t]{2}{*}{ Apogon imberbis } & & Eualus occultus (Lebour, 1936) \\
\hline & & Processa acutirostris Nouvel \& Holthuis, 1957 \\
\hline \multirow[t]{5}{*}{ Chromis chromis } & & Hippolyte sp. Leach, 1814 \\
\hline & & Jujubinus sp. Monterosato, 1884 \\
\hline & & Liljeborgia dellavallei Stebbing, 1906 \\
\hline & & Siriella clausii G.O.Sars, 1876 \\
\hline & & Synisoma appendiculatum (Risso, 1816) \\
\hline \multirow[t]{3}{*}{ Scorpaena notata } & & Cymodoce hanseni Dumay, 1972 \\
\hline & & Galathea intermedia Lilljeborg, 1851 \\
\hline & & Hippolyte sp. Leach, 1814 \\
\hline \multirow[t]{21}{*}{ Scorpaena porcus } & & Apherusa vexatrix Krapp-Schickel, 1979 \\
\hline & & Cheirocratus sundevallii (Rathke, 1843) \\
\hline & & Cymodoce hanseni Dumay, 1972 \\
\hline & & Cymodoce hanseni juv. Dumay, 1972 \\
\hline & & Eualus occultus (Lebour, 1936) \\
\hline & & Eualus pusiolus (Kroyer, 1841) \\
\hline & & Eualus sp. Thallwitz, 1891 \\
\hline & & Galathea bolivari Zariquiey A., 1950 \\
\hline & & Hippolyte inermis Leach, 1815 \\
\hline & & Hyale carinata (Bate, 1862 ) \\
\hline & & Inachus thoracicus (Roux, 1830) \\
\hline & & Liocarcinus arcuatus (Leach, 1814) \\
\hline & & Liocarcinus pusillus (Leach, 1815) \\
\hline & & Lysmata seticaudata (Risso, 1816) \\
\hline & & Macropodia sp. Leach, 1814 \\
\hline & & Munida intermedia A. Milne-Edwards \& Bouvier,1899 \\
\hline & & Palaemon sp. Weber, 1795 \\
\hline & & Platynereis dumerilii (Audouin \& Milne-Edwards, 1833) \\
\hline & & Processa acutirostris Nouvel \& Holthuis, 1957 \\
\hline & & Synisoma appendiculatum (Risso, 1816) \\
\hline & & Thoralus cranchii (Leach, 1817) \\
\hline \multirow[t]{5}{*}{ Serranus hepatus } & & Amphiura chiajei Forbes, 1843 \\
\hline & & Clibanarius erythropus (Latreille, 1818) \\
\hline & & Liocarcinus arcuatus (Leach, 1814) \\
\hline & & Phtisica marina Slabber, 1769 \\
\hline & & Processa sp. Leach, 1815 \\
\hline \multirow[t]{3}{*}{ Serranus scriba } & & Clibanarius erythropus (Latreille, 1818) \\
\hline & & Galathea bolivari Zariquiey A., 1950 \\
\hline & & Leptomysis mediterranea G.O.Sars, 1877 \\
\hline
\end{tabular}

Table 3. (Continued) 


\begin{tabular}{|c|c|}
\hline & $\begin{array}{l}\text { Processa canaliculata Leach, } 1815 \\
\text { Thoralus cranchii (Leach, 1817) } \\
\text { Vargula mediterranea Costa, } 1845\end{array}$ \\
\hline Symphodus mediterraneus & $\begin{array}{l}\text { Achelia echinata Hodge, } 1864 \\
\text { Galathea sp. Fabricius, } 1793 \\
\text { Platynereis dumerilii (Aud.\&M.Edwards, 1833) }\end{array}$ \\
\hline Symphodus ocellatus & $\begin{array}{l}\text { Callipallene brevirostris (Johnston, 1837) } \\
\text { Gnathia } \text { sp. Leach, } 1814 \\
\text { Nymphon sp. Fabricius, } 1794 \\
\text { Parategastes sphaericus Claus, } 1863 \\
\text { Praniza of Gnathia } \text { sp. Leach, } 1814 \\
\text { Synisoma appendiculatum (Risso, 1816) }\end{array}$ \\
\hline Symphodus rostratus & $\begin{array}{l}\text { Alpheus dentipes Guérin, } 1832 \\
\text { Athanas } \text { sp. Leach, } 1814 \\
\text { Cymodoce sp. Leach, } 1814 \\
\text { Galathea bolivari Zariquiey A., } 1950 \\
\text { Galathea sp. Fabricius, } 1793 \\
\text { Gnathia sp. Leach, } 1814 \\
\text { Hippolyte sp. Leach, } 1814 \\
\text { Inachus thoracicus (Roux, 1830) } \\
\text { Munida intermedia A. Milne-Edwards \& Bouvier,1899 } \\
\text { Praniza of Gnathia sp. } \\
\text { Processa macrophthalma Nouvel \& Holthuis,1957 } \\
\text { Siriella clausii G.O.Sars, } 1876 \\
\text { Synisoma appendiculatum (Risso, 1816) }\end{array}$ \\
\hline Symphodus tinca & $\begin{array}{l}\text { Cymodoce sp. Leach, } 1814 \\
\text { Galathea sp. Fabricius, } 1793 \\
\text { Harmothoe sp. Kinberg, } 1855 \\
\text { Hippolyte inermis Leach, } 1815 \\
\text { Laetmonice hystrix (Savigny, 1820) } \\
\text { Lepadogaster candollei Risso, 1810 } \\
\text { Paranthura nigropunctata (Lucas, 1849) } \\
\text { Pontogenia chrysocoma (Baird, 1865) } \\
\text { Synisoma appendiculatum (Risso, 1816) }\end{array}$ \\
\hline Syngnathus acus & $\begin{array}{l}\text { Ampelisca rubella A.Costa, } 1864 \\
\text { Anapagurus laevis (Bell, 1846) } \\
\text { Athanas nitescens (Leach, 1814) }\end{array}$ \\
\hline
\end{tabular}

high numerical abundance; more individuals were caught in winter, probably due to the greater winter efficiency of the trawl in the lower canopy or to lower trophic resources of surrounding benthic systems [34]. Differences in the abundance of species at the three sites were demonstrated to be not significant, and several species were present with a low number of individuals and low biomass Therefore we focused our investigation upon the most abundant species, i.e., the foremost 14 reported in Table 1. Most of the sampled fish species are carnivorous and should represent the top consumers within the meadow [7,33]. However, seasonal variations in the diet (plant or animal) of some species were detected in the present investigation.

The genus Symphodus was the most abundant, accounting for more than $40 \%$ of the total fish population. 


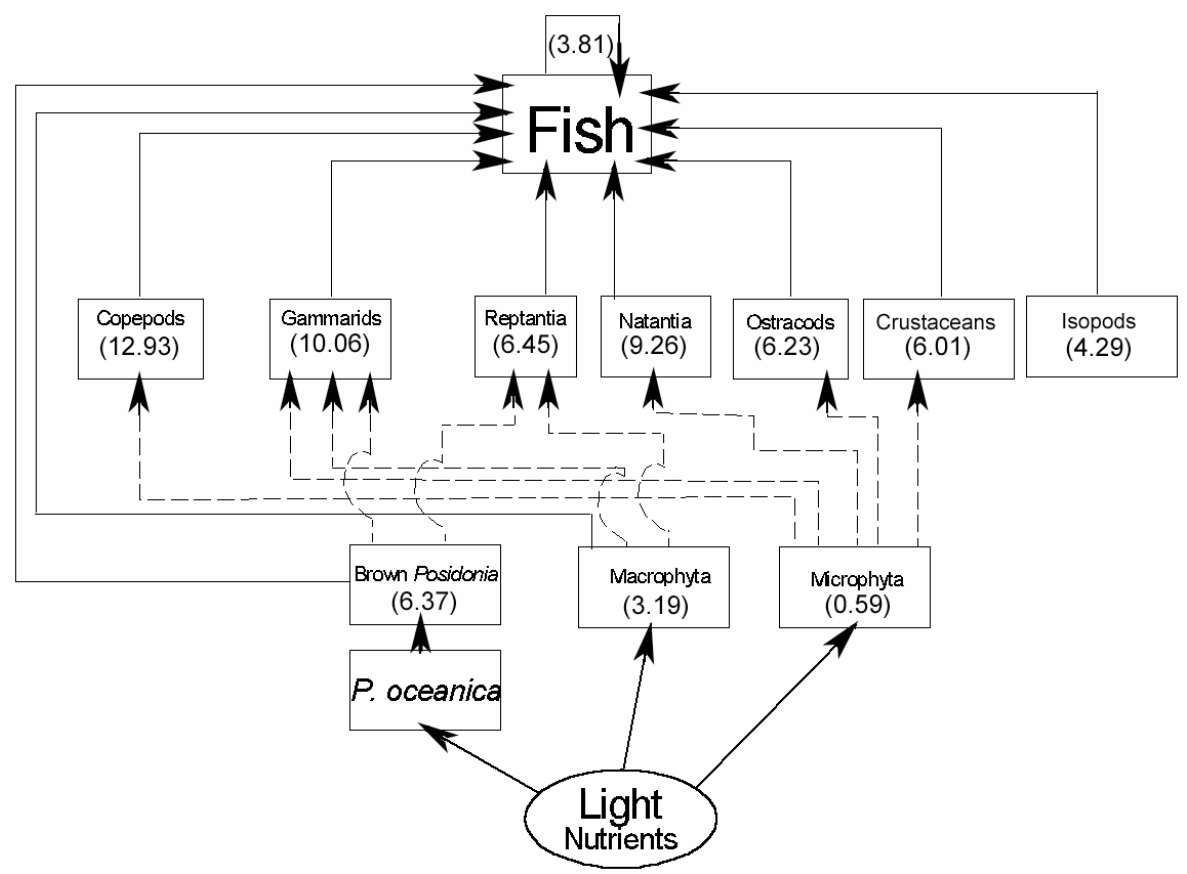

Figure 7. Pathways of matter transfer (volumes of gut contents) in the fish food webs, based on the data of the present paper (solid links between secondary producers and fish) and literature data (dotted links between primary producers and secondary producers; see text). Only vertical links were taken into account, to highlight the role of fish predation. The fish compartment is mainly represented by Labridae, Pomacentridae, Scorpaenidae and Serranidae. Numbers in parenthesis indicate the average volumes occupied by each item in the guts.

The diet of species in this genus was based on vagile organisms of the leaf stratum, grazers of the epiphyte layer. Therefore the genus Symphodus represents one of the pathways from secondary producers within the leafstratum to the export chain. The large spectrum of prey items found in the guts of the most abundant species, Symphodus ocellatus and S. rostratus, indicates high trophic adaptability, and this may be responsible for theirsuccess within the studied meadows, as documented by their abundance. In contrast, the diet of the most abundant species, Chromis chromis, was based on a few items, scarcely present in the guts of other fish. Therefore, this species has the advantage to use a rich, unexploited microphagous trophic niche. Other abundant species, such as Scorpaena porcus and Serranus scriba, fed almost exclusively on abundant [5] items in the meadow (e.g., decapod crustaceans and gammarid amphipods). Symphodus rostratus, S. porcus and S. scriba were efficient predators of decapod crustaceans, since deca pods accounted for more than $30 \%$ of their gut volume. The abundance of these three species of fish may explain the high predation pressure observed on various decapod populations $[35,36]$.

The diet of $S$. ocellatus and S. mediterraneus, in contrast, was based on smaller crustaceans (copepods and amphipods) accounting for more than $30 \%$ of their gut volume. The abundance of brown tissues of Posidonia in the guts of these species indicates that it is not an occasional item, although the actual trophic role of leaf detritus is unclear [37]. It could be used per se, or ingested to digest bacteria and small prey present on its surface $[25,38,39]$.

The ordination of species in the "Type-Size" plots confirmed that fish play essentially a macro-carnivore role in the meadow food webs. Given the low rate of recycling (fish represented less than $4 \%$ of prey in the gut contents), it may be assumed that most of the biomass produced within the system is exported to other coastal systems through predation by fish swimming over the canopy, or lost through fishing activities [6]. The main variations were observed in the "Type" index, indicating that some species, such as Symphodus cinereus and Labrus viridis, can adapt their diets according to the availability of animal or plant items, while the average size of their prey did not vary. However, the diets of the most abundant species exhibited slight seasonal variations. The prey taxa consumed by most fish were abundant throughout the year [5], although variations of prey at a lower taxonomic level (i.e., species) were detected (Table 3).

The three dominant species of fish showed seasonal variations of prey at species level and some prey-species, 
abundant in the gut contents in summer (such as Hippolyte inermis) were absent in winter (Table 3 ), according to their known [35] seasonal patterns of abundance in the meadows.

They were replaced in the diet by prey-species with a similar shape and size, such as Eualus sp. and Processa acutirostris. The seasonality in the prey availability was also demonstrated by the fact that such fish as $S$. ocellatus, $S$. rostratus, and $S$. porcus, showed a larger diet spectrum in summer than in winter.

The ordination of species in the "Type-Size" space according to sites indicated that fish sampled off the island of Procida used prey characterised by a broader spectrum of sizes, as compared to the other two meadows. In fact, the maximum "Size" index reached by fish sampled at Lacco Ameno and San Pancrazio was about 1, while some species sampled at Procida, such as Mullus surmuletus, S. scriba and S. porcus, reached higher Size index scores. The comparable size of these fish species at the three sites suggests that differences shown in the Size index are dependent on prey availability.

A diagram of the main pathways of transfer, from primary producers to the top-level predators, can be drawn for the investigated $P$. oceanica meadows, based on the data of the present work and literature information on the feeding habits of the most abundant grazers. The guts contained mainly small invertebrates, typical of the leaf stratum, feeding on microphyta, macrophyta, and Posidonia detritus [12,40-44]. Taking into account the abundance (\% of gut volume) of each food item in the two seasons, $12.9 \%$ of prey (in terms of gut volume) was represented by copepods, feeding, in their turn, mainly on diatoms and bacteria $[34,41,45,46]$. Gammarid amphipods accounted for $10.0 \%$ of fish prey and they feed mainly on micro-algae [47-51]. Reptantia decapods accounted for $6.4 \%$ of the fish prey and they feed mainly on Posidonia detritus and macrophyta [18], although horizontal links should be taken into account [52]. In fact, reptantia decapods also feed on other secondary producers, such as natantia decapods, amphipods, copepods, molluscs, tanaidacea, isopods, sipunculids, polychaetes $[19,43,53,54]$. Natantia deca pods accounted for $9.2 \%$ of the fish prey and they feed mainly on micro-algae and small organisms of the leaf stratum (amphipods, copepods, acarids; [5,35]), although horizontal links should be taken into account and also for this taxon $[43,52,55,56]$. Ostracods accounted for $6.2 \%$ of fish prey and they feed mainly on micro-algae [26,34]. Other small crustaceans accounted for $6.1 \%$ of the fish prey and they feed mainly on nematodes, copepods, and ciliates [57]. Isopods accounted for $4.3 \%$ of the fish prey and they mainly feed on micro-algae and detritus [58]. A low recycling rate in the fish compartment must be taken into account, since it was calculated that $3.8 \%$ of fish prey is represented by teleosts. Scorpaenidae, Serranidae, Pomacentridae and Congridae were the main fish feeders.

Our data indicated a pathway of transfer from Posidonia detritus, macrophyta and microphyta (as primary producers) to crustacean decapods, copepods, ostracods, and gammarid amphipods (as secondary producers) to fish (as consumers), mainly represented by Labridae, Pomacentridae, Scorpaenidae, and Serranidae. The rate of recycling through these families is low (about 4\%). Crustacean decapods represent another important loop of biomass recycling, since they can feed also on the other secondary producers described above $[14,18]$. Therefore, besides natural mortality, the biomass stocked in the fish compartment (in terms of volumes) may be exported to other systems by means of predation by other fish [33], non resident in the meadows and characterised by higher swimming capabilities, such as Sparidae, larger Serranidae, and Congridae.

A comparison with studies in other seagrasses $[10,13,20,59,60,61]$ and different sites of the Mediterranean [33] allows for detecting a general trend of fish assemblages, with respect to the feeding behaviour of dominant species. They generally show a clear preference for epibenthic fauna and extensively feed on crustaceans. Only few herbivorous and herbivorous-detritivorous species were detected in $P$. oceanica meadows, despite the large abundance of plant material available. In contrast, herbivorous and omnivorous fish are common in other seagrass communities $[28,60,61,62]$, characterised by a larger variety of trophic levels. Most species were carnivorous, both macrophagic and microphagic, in accordance with the results obtained in French $P$. oceanica meadows [33]. The only herbivorous fish, well known in Mediterranean seagrass meadows, is Sarpa salpa (L.) [33]; however this species is generally restricted to shallow meadows (less than $10 \mathrm{~m}$ depth), characterised by a higher abundance of plant epiphytes. Therefore, it did not occur in the depth range investigated in the present paper and its feeding impact scarcely influences the food webs of deeper meadows, exhibiting a higher stability and complexity.

Labride are consistently dominant in Mediterranean $P$. oceanica meadows [22] and they feed on a broad spectrum of prey items, with a preference for crustaceans (mainly amphipods and decapods). However, they can adapt their diet according to the site and the time of sampling. In fact, our analyses indicated seasonal changes in the diet of some species and a lower abundance of molluscs in their gut contents, as compared to the results of [33]. Gastropod molluscs were mainly consumed by Chromis chromis, the most abundant species. In contrast, Labridae may be considered as mesophagic carnivores [33] feeding on copepods, gam- 
marid amphipods, decapods, ostracods and other crustaceans, as well as molluscs. Decapods and other small crustaceans of the leaf stratum were demonstrated to be keystone items in the fish food webs [36], transferring biomass from the primary producers to the top predators. This trend appears to be a general feature of seagrass meadows $[60,63]$, since it is in accordance with the results obtained in other seagrass ecosystems, both temperate and tropical.

\section{ACKNOWLEDGEMENTS}

We are indebted to P. Francour for the collection of samples in Ischia. We are grateful to M.C. Gambi, M.B. Scipione and M. Lorenti for their assistance in the determination of species. D. Stübing was supported by a COMETT fellowship, Europäischer Praktikantenaustausch. Mrs R. Messina revised the English text.

\section{REFERENCES}

[1] Khoury, C. (1984) Ethologies alimentaires de quelques espèces de poissons de l'herbier de Posidonies du Parc National de Port-Cros. International workshop on Posidonia oceanica beds. In: Boudouresque C.F. et al. Eds., GIS Posidonie, Marseilles, France, 1, 335-347.

[2] Edgar, G.J. and Shaw, C. (1993) Relationships between sediments, seagrasses, benthic invertebrates and fishes in shallow marine habitats off South-Western Australia. Proceedings of the fifth International marine Biological Workshop: the flora and fauna of Rottnest Island, Western Australia, In: Wells, F.E. and Walker, D.I. Eds., Western Australian Museum, Perth, Australia, 429-442.

[3] Minello, T.J. (1993) Chronographic tethering-a technique for measuring prey survival time and testing predation pressure in aquatic habitats. Marine Ecology Progress Series, 101, 99-104.

[4] Bell, J.D. and Westoby, M. (1986) Abundance of macrofauna in dense seagrass is due to habitat preference, not predation. Oecologia, 68, 205-209.

[5] Gambi, M.C., Lorenti, M., Russo, G.F., Scipione, M.B. and Zupo, V. (1992) Depth and seasonal distribution of some groups of vagile fauna of Posidonia oceanica leaf stratum: structural and trophic analyses. P.S.Z.N.I.: Marine Ecology, 13, 17-39.

[6] Valentine, J.F., Heck, K.L., Blackmon, D., Goecker, M.E., Christian, J., Kroutil, R.M., Peterson, B.J., Vanderklift, M.A., Kirsch, K.D. and Beck, M. (2008) Exploited species impacts on trophic linkages along reef-seagrass interfaces in the Florida keys. Journal of Ecology Applied, 18, 1501-1515.

[7] Schultz, S.T., Kruschel, C. and Bakran-Petricioli, T. (2009) Influence of seagrass meadows on predator-prey habitat segregation in an Adriatic lagoon. Marine Ecology Progress Series, 374, 85-99.

[8] Heck, K.L. and Orth, L.M. (1980) Seagrass habitats: The role of habitat complexity, competition and predation in structuring associated fish and motile macroinvertebrate assemblages. In: Kennedy V.S. Ed., Estuarine perspectives, Academic Press, New York, 449-464.
[9] Connolly, R.M. (1994a) The role of seagrass as preferred habitat for juvenile Sillaginodes punctata (Cuv and Val) (Sillaginidae, Pisces)-habitat selection or feeding. Journal of Experimental Marine Biology and Ecology, 180, 39-47.

[10] Carr, W.E.S. and Adams, C.A. (1973) Food habits of juvenile marine fishes occupying seagrass beds in the estuarine zone near Crystal River, Florida. Transactions of the American Fisheries Society, 102, 511-540.

[11] Middleton, M.J., Bell, J.D., Burchmore, J.J., Pollard, D.A. and Pease, B.C. (1984) Structural differences in the fish communities of Zostera capricorni and Posidonia australis seagrass meadows in Botany Bay, New South Wales. Aquatic Botany, 18, 89-109.

[12] Zupo, V. (2001) Influence of diet on sex differentiation of Hippolyte inermis Leach (Decapoda: Natantia) in the field. Hydrobiologia, 449, 131-140.

[13] Burfeind, D.D., Tibbetts, I.R. and Udy, J.W. (2009) Habitat preference of three common fishes for seagrass, Caulerpa taxifolia, and unvegetated substrate in Moreton Bay, Australia. Environ. The Journal of Fish Biology, 84, 317-322.

[14] Pollard, D.A. (1984) A review of ecological studies on seagrass-fish communities, with particular reference to recent studies in Australia. Aquatic Botany, 18, 3-42.

[15] Robertson, A.I. (1984) Trophic interactions between the fish fauna and macrobenthos of an eelgrass community in Western Port, Victoria. Aquatic Botany, 18, 135-153.

[16] Baird, D., Asmus, H. and Asmus, R. (2007) Trophic dynamics of eight intertidal communities of the Sylt-Rømø Bight ecosystem, northern Wadden Sea. Marine Ecology Progress Series, 351, 25-41.

[17] Mazzella, L., Buia, M.C., Gambi, M.C., Lorenti, M., Russo, G.F., Scipione, M.B. and Zupo, V. (1992) Plant-animal trophic relationships in the Posidonia oceanica ecosystem of the Mediterranean Sea: A review. Plant-Animal Interactions in the Marine Benthos. In: John D.M. et al. Eds., Systematics Association, Special, Clarendon Press, Oxford, UK, N6, 165-187.

[18] Zupo, V. (1993) The use of feeding indices for the study of food webs: an application to a Posidonia oceanica ecosystem. Coenoses, 8, 85-95.

[19] Gloeckner, D.R. and Luczkovich, J.J. (2008) Experimental assessment of trophic impacts from a network model of a seagrass ecosystem: Direct and indirect effects of gulf flounder, spot and pinfish on benthic polychaetes. Journal of Experimental Marine Biology and Ecology, 357, 109-120.

[20] Brook, I.M. (1977) Trophic relationships in a seagrass community (Thalassia testudinum) in Card Sound, Florida. Fish diets in relation to macrobenthic and cryptic faunal abundance. Transactions of the American Fisheries Society, 106, 219-229.

[21] Burchmore, J.J., Pollard, D.A. and Bell, J.D. (1984) Community structure and trophic relationships of the fish fauna of an estuarine Posidonia australis seagrass habitat in Port Hacking, New South Wales. Aquatic Botany, 18, 71-87.

[22] Bell, J.D. and Harmelin-Vivien, M.L. (1982) Fish fauna of French Mediterranean Posidonia oceanica seagrass meadows. I-Community structure. Téthys, 10, 337-347. 
[23] Connolly, R.M. (1994b) Removal of segrass canopy: effects on small fish and their prey. Journal of Experimental Marine Biology and Ecology, 184, 99-110.

[24] Kemp, S.J. (2008) Autecological effects of habitat alteration: trophic changes in mangrove marsh fish as a consequence of marsh impoundment. Marine Ecology Progress Series, 371, 233-242.

[25] Velimirov, B., Ott, J.A. and Novak, R. (1981) Microorganisms on macrophyte debris: Biodegradation and its implication in the food web. Kieler Meeresforsch. Sonder, 5, 333-344.

[26] Van Montfrans, J., Wetzel, R.L. and Orth, R.J. (1984) Epiphyte-grazers relationships in seagrass meadows: Consequences for seagrass growth and production. Estuaries, 7, 289-309.

[27] Zupo, V. (1990) The food web of Posidonia oceanica beds around the island of Ischia (Gulf of Naples, Italy) A new trophic index. Rapports et Proces Verbaux des Reunions-Commission Internationale pour l'Exploration Scientifique de la Mèr Méditerranee, 32, 16-16.

[28] Bologna, P.A.X. (2007) Impact of differential predation potential on eelgrass (Zostera marina) faunal community structure. Aquatic Botany, 41, 221-229.

[29] Harmelin-Vivien, M.L. and Francour, P. (1992) Trawling or visual censuses? Methodological bias in the assessment of fish populations in seagrass beds. P.S.Z.N.I.: Marine Ecology, 13, 41-51.

[30] Harmelin-Vivien, M.L. (1981) Description d'un petit chalut à perche pour récolter la faune vagile des herbiers de Posidonies. Rapports et Proces Verbaux des Reunions-Commission Internationale pour l'Exploration Scientifique de la Mèr Méditerranee, 27, 199-200.

[31] Chessa, L.A., Fresi, E. and Soggiu, L. (1982) Primi dati sulla rete trofica dei consumatori in una prateria di Posidonia oceanica (L.) Delile. Bollettino del Museo Istituto di Biologia Università di Genova, 50, 156-161.

[32] Hansson, S. (1998) Methods of studying fish feeding: Acomment. Canadian Journal of Fisheries and Aquatic Sciences, 55, 2706-2707.

[33] Bell, J.D. and Harmelin-Vivien, M.L. (1983) Fish fauna of French Mediterranean Posidonia oceanica seagrass meadows. II - Feeding habits. Téthys, 11, 1-14.

[34] Montagna, P.A., Blanchard, G.F. and Dinet, A. (1995) Effect of production and biomass of intertidal microphytobenthos on meiofaunal grazing rates. Journal of Experimental Marine Biology and Ecology, 185, 149-165.

[35] Zupo, V. (1994) Strategies of sexual inversion in Hippolyte inermis Leach (Crustacea, Decapoda) from a Mediterranean seagrass meadow. Journal of Experimental Marine Biology and Ecology, 178, 131-145.

[36] Zupo, V. (2006) Decapod associations from "Banco di Santa Croce" (Bay of Naples): A key pathway in local food webs. Biologia Marina Mediterranea, 13(1), 456-466.

[37] Lawrence, J.M., Boudouresque, C.F. and Maggiore, F. (1989) Proximate constituents, biomass, and energy in Posidonia oceanica (Potamogetonaceae). P.S.Z.N.I.: Marine Ecology, 10, 263-270.

[38] Cuomo, V., Vanzanella, F., Fresi, E., Mazzella, L. and Scipione, M.B. (1982) Microflora delle fanerogame dell'isola d'Ischia: Posidonia oceanica (L.) Delile e Cymodocea nodosa (Ucria) Aschers. Bollettino del Museo Istituto di Biologia Università di Genova, 50, 162-166.

[39] Kitting, C.L., Fry, B. and Morgan, M.D. (1984) Detection of inconspicuous epiphytic algae supporting food webs in seagrass meadows. Oecologia, 62, 145-149.

[40] Lorenti, M. and Fresi, E. (1983) Grazing of Idotea baltica basteri on Posidonia oceanica: Preliminary observations. Rapports et Proces Verbaux des Reunions-Commission Internationale pour l'Exploration Scientifique de la Mèr Méditerranee, 28, 147-148.

[41] Orth, R.J. and Van Montfrans, J. (1984) Epiphyte-seagrass relationships with an emphasis on the role of micrograzing: a review. Aquatic Botany, 18, 43-69.

[42] Bedford, A.P. and Moore, P.G. (1985) Macrofaunal involvement in the sublittoral decay of kelp debris: the polychaete Platynereis dumerilii (Audouin and Milne-Edwards) (Annelida: Polychaeta). Estuarine, Coastal and Shelf Science, 20, 117-134.

[43] Zupo, V. and Fresi, E. (1985) A study on the food web of the Posidonia oceanica (L.) Delile ecosystem: Analysis of the gut contents of decapod crustaceans. Rapports et Proces Verbaux des Reunions-Commission Internationale pour l'Exploration Scientifique de la Mèr Méditerranee, 29, 189-192.

[44] Mazzella, L. and Russo, G.F. (1989) Grazing effect of two Gibbula species (Mollusca, Archaeogastropoda) on the epiphytic community of Posidonia oceanica leaves. Aquatic Botany, 35, 357-373.

[45] Barr, M.W. (1969) Culturing the marine harpacticoid copepod Tisbe furcata (Baird 1837). Crustaceana, 16, 95-96.

[46] Nassogne, A. (1970) Influence of food organisms on the development and culture of pelagic copepods. Helgolander Wissenschaftliche Meeresunter-suchungen, 20, 333-345.

[47] Howard, R.K. (1982) Impact of feeding activities of epibenthic amphipods on surface-fouling of eelgrass leaves. Aquatic Botany, 14, 91-97.

[48] Hay, M.E., Duffy, J.E., Pfister, C.A. and Fenical, W. (1987) Chemical defenses against different marine herbivores: Are amphipods insect equivalent? Ecology, 68, 1567-1580.

[49] Scipione, M.B. (1989). Comportamento trofico dei crostacei anfipodi in alcuni sistemi bentonici costieri. Oebalia, 15, 249-260.

[50] Lorenti, M. and Scipione, M.B. (1990) Relationships between trophic structure and diel migrations of isopods and amphipods in a Posidonia oceanica bed of the Island of Ischia. Rapports et Proces Verbaux des ReunionsCommission Internationale pour l'Exploration Scientifique de la Mèr Méditerranee, 2, 17-17.

[51] Scipione, M.B. and Mazzella, L. (1992) Epiphytic diatoms in the diet of crustacean amphipods of Posidonia oceanica leaf stratum. Oebalia, 17, 409-412.

[52] Nelson, W.G. (1981a) The role of predation by decapod crustaceans in seagrass ecosystems. Kieler Meeresforschung Sonderheim, 5, 529-536, 
[53] Nelson, W.G. (1981b). Experimental studies of decapod and fish predation on seagrass macrobenthos. Marine Ecology Progress Series, 5, 141-149,

[54] Chessa, L.A., Scardi, M., Fresi, E. and Saba, S. (1989b) Consumers in Posidonia oceanica beds: 2. Galathea squamifera Leach (Decapoda, Anomura). II International workshop on Posidonia beds. In: Boudouresque, C.F. et al. Eds., GIS Posidonie, Marseilles, France, 2, 251-256.

[55] Bell, S.S. and Coull, B.C. (1978) Field evidence that shrimp predation regulates meiofauna. Oecologia, 35, 141-148

[56] Chessa, L.A., Scardi, M., Fresi, E. and Russu, P. (1989a) Consumers Posidonia oceanica beds: 1. Processa edulis (Risso), (Decapoda, Caridea). In: II International workshop on Posidonia beds. In: Boudouresque, C.F. et al Eds., GIS Posidonie, Marseilles, France, 2, 243-250.

[57] Ambler, J.W., Alcalaherrera, J., Burke, R. (1994) Trophic roles of particle feeders and detritus in a mangrove island prop root ecosystem. Hydrobiologia, 293, 437-446.

[58] Klumpp, D.W., Howard, R.K. and Pollard, D.A. (1989) Trophodynamics and nutritional ecology of seagrass communities. Biology of seagrasses, 2. In: Larkum, A.W.D. et al. Eds., Elsevier, Amsterdam, 394-457.

[59] Randall, J.E. (1965) Grazing effect on seagrass by herbivorous reef fishes in the West Indies. Ecology, 46, 225-260.

[60] Adams, S.M. (1976) Feeding ecology of eelgrass fish communities. Transactions of the American Fisheries Society, 105, 514-519.

[61] Bell, J.D., Burchmore, J.J. and Pollard, D.A. (1978) Feeding ecology of three sympatric species of leather jackets (Pisces: Monacanthidae) from a Posidonia seagrass habitat in New South Wales. Austr. Journal of marine and freshwater research, 29, 631-643.

[62] Kikuchi, T. (1966) An ecological study on animal communities of the Zostera marina belt in Tomioka Bay, Amakusa, Kyushu. Publ. Amakusa. Marine Biological Laboratory, 1, 1-106.

[63] Zupo, V. and Nelson, W.G. (1999) Factors influencing the association patterns of Hippolyte zoostericola and $\mathrm{Pa}$ laemonetes intermedius (Decapoda: Natantia) with seagrasses of the Indian River Lagoon, Florida. Marine Biology, 134, 181-190. 